\title{
Political Changes in Hungary After the Soviet Invasion of Czechoslovakia
}

When the economic reform (NEM) was introduced in Hungary in early 1968, it was announced that political reforms aiming at the "democratization of the socialist system" would also be made. ${ }^{1}$ The Hungarian Socialist Workers' Party (MSZMP) and the government stated that economic decentralization would be accompanied by the "strengthening of socialist democracy and the broadening of the participation of the masses in political activities." Several measures were taken to promote this objective through discussion and debatebut not through dissent or decision-making. After the Soviet invasion of Czechoslovakia in August 1968, which seriously affected the entire East European bloc, Hungary's move toward democratization became less pronounced and the government's policy definitely more cautious both in words and deeds. In this study I attempt to analyze the meaning and scope of the political changes that took place in Hungary in the aftermath of Czechoslovakia, giving special attention to the concept of democracy, the organization of the party and government, the position of the mass organizations, and the meaning of the increasing group conflicts.

\section{The Concept of Democracy}

In conjunction with the implementation of the NEM and the proposed democratization some broadening of the political process took place in 1967 and early 1968, minute though it was. For example, the introduction of the individual district system can be regarded as some improvement, even though the change really meant very little, since there is no place for real political opposition in the National Assembly. ${ }^{2}$ Also at the Fourth Congress of the Patriotic People's Front (PPF), it was the National Council, rather than the secretary or the president, that submitted the report to the congress which solemnly declared that "the broadening of socialist democracy, together with

1. The basic features of the NEM (New Economic Mechanism) are fundamentally similar to the reforms of other bloc countries, although there are some differences among them in scope and degree. See United Nations, Economic Survey of Europe, 1965, pt. 1, p. 57.

2. Note the following editorial statement: "Socialism does not have to tolerate an opposition against it because it represents in itself the interest of the working masses," Népszabadság (Budapest), Mar. 3, 1968, p. 5. 
the economic reform, is an important step toward the completion of the building of socialism." However, no specific proposals were put forward, and the definition of democracy remained extremely restricted. As Rezső Nyers, a member of the Political Bureau put it, "Democracy is a particular means in the hands of the masses to direct and supervise social and economic functions." 3 But even this limited democracy failed to find expression under the reform. First Secretary of the MSZMP, János Kádár, made it plain that the party, while relying on the other social organizations, was determined to maintain and strengthen its leading role. ${ }^{4}$

Although there was much discussion of democratization in the first half of 1968, the NEM had only a minor impact upon political institutions. Gyula Kállai, a member of the Political Bureau, denied Western allegations that the NEM would inevitably precipitate far-reaching social and political reforms and ruled out the possibility of decentralization in political life. The admitted objective of the party was still defined as "the completion of the building of socialism according to Marxism-Leninism," and democracy was interpreted by Kádár in this orthodox way: "Naturally I have to stress that we do not mean democracy in general and without any restrictions. Democracy in general does not exist, and it never existed in the world. All democracies were democracies of some ruling class. Ours is the democracy of the working class, the workers' socialist democracy."5

It is noteworthy that in the summer of 1968, at the same time that the Soviet pressure upon Czechoslovakia was gradually unfolding, the MSZMP repeatedly emphasized that the party would remain in the center of power and that the NEM would not change this fact. ${ }^{6}$ Moreover, after the invasion, the party conducted a propaganda campaign-reminiscent of Stalinist times-in which it stressed anew the Leninist concepts of "democracy," thus causing even the moderate attempts at the broadening of the political process to wither away, though lip service was still paid to the strengthening of socialist democracy. Thus Kádár found it necessary to recall in October 1968 that the Ninth Congress of the party had decided not to change the main lines of foreign and domestic policy, but rather to reinforce them, and he declared that this was exactly what had happened during the last two years.

3. Rezső Nyers, member of the Political Bureau, "The Impact of the Economic Reform Upon the Society," Társadalmi Szemle (Budapest), March 1968, p. 16.

4. Statement on the Congress of the PPF, Népszabadság, Apr. 19, 1968; see also Apr. 24, 1968, p. 2.

5. Magyar Nemzet (Budapest), June 11, 1968, p. 4.

6. See, for example, the Statement by Sándor Lakos, director of the Sociological Institute of the MSZMP Political Academy, Népszabadság, June 4, 1968, p. 5; Népszabadság, June 13, 1968, p. 4 ; Gyula Kállai, member of the Political Bureau and president of the National Assembly, "Economic Reform and the Development of Society," Társadalmi Szemle, June 1968, p. 11. 
It became unequivocally clear after Czechoslovakia that by "democratization" the MSZMP does not mean concessions that would permit the introduction of several political parties or the tolerance of dissent in regard to fundamental views: the system of government is officially defined as being the dictatorship of the proletariat, which is held to be the most highly developed form of democracy. ${ }^{7}$ It was conceded, however, that economic reform could not succeed unless some changes in the administrative machinery were made and a more intimate and active relation between the representative institutions and the electors established. Nevertheless, even this limited concept of democratization is strictly qualified: any participation by the working people is supposed to strengthen socialism and contribute to its completion.

The strict limitations that the party places on democratization are revealed by its declaration that there is no need to create new political organs but rather that the institutions already in existence should be improved. The party takes the position that the realization of democracy also makes the preservation of the "socialist discipline of the masses" ( $s i c$ ) imperative and that all measures taken to increase socialist production simultaneously promote the development of democracy. This view suggests that any improvement of the economy indirectly strengthens democracy, but even this untenable statement is qualified by the warning that participation in public affairs must be inspired by socialist consciousness; otherwise such action is merely irresponsible meddling.

The excessive concern over the interpretation of "democratization" clearly shows that the lessons of 1956 and Czechoslovakia are vivid in the minds of the party leaders: "the infiltration of bourgeois content into the concept of democracy, as happened in Czechoslovakia, endangers the socialist democracy and has to be overcome." ${ }^{\prime 8}$ It is no surprise, then, that the validity of the convergence theory is emphatically denied, and that instead of making concessions that would lead toward a truly democratic system, the party is putting its efforts into maintaining absolute control, and is still upholding democratic centralism as the fundamental principle of "democratism" in all spheres of political life. ${ }^{9}$ The position of the MSZMP on these issues was fully endorsed by the Soviet Communist Party (Pravda, February 7, 1969). p. 3 .

7. Gyula Kállai, "Socialist Democracy, Socialist State," Népszabadság, Dec. 24, 1968,

8. Endre Kálmán, editor of Társadalmi Szemle, "The Variations and Potentialities of Democracy," Társadalmi Szemle, August-September 1968, p. 12. Endre Kálmán, "The Slogan of Democratic Socialism and Reality," Társadalmi Szemle, December 1968, pp. 14-23. For the rigid and authoritarian concept of democracy, see Valéria Benke, member of the Central Committee, "Unbroken Policy," Társadalmi Szemle, October 1968, pp. 3-16; see also Zoltán Komócsi, member of the Political Bureau and secretary of the Central Committee, "National Interests and the Principles of Proletarian Internationalism," Népszabadság, Apr. 4, 1969, pp. 1-2.

9. Béla Biszku, member of the Political Bureau and secretary of the Central Com- 
In the light of this clear and unmistakable policy it appears that those Western opinions which still suggest the possibility of a trend toward the liberalization of Hungarian political institutions as an inevitable by-product of the economic reforms have not been borne out.

\section{The Party in the Political Process}

The official view defines "democracy" as the rule of the working class instructed and directed by the party, which has the leading role. However, after the implementation of the NEM, a new trend was observable which suggested that the party should withdraw from certain areas of life. ${ }^{10}$ The MSZMP never yielded to this pressure, and as mentioned above, First Secretary János Kádár stressed that the party, although it relied on the other social organizations, was determined to maintain and strengthen its leading role.

As the movement for reform and change in Czechoslovakia accelerated, and especially after the Soviet invasion, the MSZMP became anxious to reassert its role as the exclusive source of political power. Gyula Kállai, a member of the Political Bureau, stated: "The center of politics in our country is the party. Therefore, we have to strengthen the leading role of the party, without which there is no progress."11 Many speeches and statements by party and government leaders make the point clear. Kádár, recalling the resolutions of the Ninth Congress, restated once again that the important program of the party is "the further strengthening of the 'people's power' and the party's role." 12 The most authoritative recent statement declared, "In the present phase of the building of socialism it is necessary to strengthen the ideologicalpolitical leadership of the party."13 The ideological foundations of the party remained the tenets of Leninism, democratic centralism, and-what was repeatedly emphasized by party leaders-the "two-front struggle against dogmatism, leftist sectarianism, revisionism, and counterrevolutionary tendencies."14

mittee, "A Few Actual Questions About the Leading Role of the Party," lecture on the Political Academy of the MSZMP, Népszabadság, Mar. 13, 1969, p. 3. Imre Pozsgai, secretary of the Bács County Party Bureau, "Selected Problems of the Development of the Socialist Democracy," Társadalmi Szemle, October 1968, p. 20; see for the discussion of the principle in the state apparatus, Gyula Kállai, "Actual Questions of the Life of the Socialist State," Népszabadság, May 9, 1969, pp. 5-6.

10. See the debate between Péter Veres and József Bognár, "Between Hopes and Fears," Népszabadság, Nov. 12, 1967, p. 9 (reference to suggestions that the party should reduce its involvement in economic and cultural matters).

11. Társadalmi Szemle, June 1968, p. 2.

12. Magyar Nemzet, Oct. 25, 1968, p. 2.

13. Common Declaration of the Central Committee of the MSZMP and the Revolutionary Worker-Peasant Government on the March 5-6 joint meeting, Népszabadság, Mar. 8, 1969, p. 1.

14. Speech by János Kádár on the occasion of the fiftieth anniversary of the foundation 
If there is little real "democratization" in the government and mass organizations, there is even less in the party. The term itself is interpreted in a very rigid manner. According to the pronouncements of party leaders, current interpretations of intraparty democracy by many members often result in "collective criticism" and the admission of "failures and deficiencies," but individual responsibilities are disregarded. Party leaders consider that members who have fallen into such errors are interpreting intraparty democracy erroneously. Party spokesmen stress the importance of individual self-criticism and refute this kind of "democratic" enlargement of responsibility. ${ }^{15}$

As in the economic and governmental organs, there is in the party a lack of genuine criticism from below. Most criticism is directed by higher organs against lower ones, and the latter are reluctant to criticize because of fear of reprisal. Although open "comradely" debates are formally recognized as fulfilling an important role in a political system in which there is no opposition, Communists are warned that there cannot be individual opinions on fundamental political questions. Independent opinion and criticism are encouraged, however, in secondary matters, provided that they serve the objectives of the party constructively. ${ }^{16}$ Nevertheless, many party members fear to express their views, and some have actually experienced reprisals for doing so.

The key organizational principle remains "democratic centralism," which assures the leading role of the higher organs in the party structure. Prevailing interpretations and applications of this principle do not show any deviation from earlier practices. The decisions of the party organs regarding membership and disciplinary questions must be approved by the higher party bureaus, whose decision is binding, but it is recommended that they explain their position and convince the members of the lower organs of the rationale of the decision. This is called "healthy fusion of democracy and centralism in the party."

In the 1968 election of the party bureaus, official candidates-selected by nominating committees-were elected in the overwhelming majority of cases, and the power of the higher organs to approve the election results was maintained. ${ }^{17}$ In some instances, however, the primary organizations refused to elect or re-elect the officially nominated secretaries and chose other candidates nominated from the floor without veto by the higher organs. ${ }^{18}$ These actions

of the party, Népszabadság, Nov. 24, 1968, p. 1; see also statement by Béla Biszku, Társadalmi Szemle, January 1969, p. 5.

15. "The Status of the Party Democracy," an analysis of the work of the Fourteenth District Party Committee in Budapest, Népszabadság, Mar. 12, 1969, p. 4.

16. Biszku, "A Few Actual Questions," pp. 3-4; see also Népszabadság, Apr. 27, 1969 , p. 3.

17. "In the Name of Unity and Responsibility," Népszabadság, Dec. 15, 1968, p. 3. It is pointed out that in only about 2 to 3 percent of the cases were the official candidates not elected.

18. In order to be placed on the ballot the candidate must be recommended by the 
were almost unprecedented and show that the membership has gained a somewhat more independent position. They do not, however, indicate the existence of an intraparty opposition. The entire procedure is firmly under the control of higher organs, which retain the right to make the final decisions; thus the central direction of the party is secured.

The analysis of the elections also shows that quite a number of primary organizations have only a nominal existence and that the members do not take a substantial part in party life. This finding not only suggests the apathy of the rank-and-file members but is also a sign that the MSZMP_-just as before 1956-includes many members who, to say the least, are more opportunistic than dedicated. The dictatorial attitudes of the Party Bureau members and their lack of communication with the membership was also criticized in election meetings. Thus party policy in the economic and government organs is shaped more by the party leadership than by the rank-and-file party membership.

The party has remained the "main guiding force" in life, and its existence is felt everywhere. Those Western observers who expected that the economic reforms would almost spontaneously lead to a gradual contraction of party power in many areas did not prove to be correct. On the contrary, the NEM resulted in the strengthening of the power of the party in some sectors of the economy. As one author expressed it, "the party organizations found their proper role in management, and there is more politics in the economic life than before."19 Although it is true that the labor unions have a somewhat enlarged role, the MSZMP holds the mass organizations under firm control. Also, in the government organs, the resolutions of the Ninth Congress authorized the party organizations to exercise control and to request reports from the heads of government offices. ${ }^{20}$

In addition, a newly created organ on the county level strengthens the influence of the party organizations with regard to propaganda. These "educational directorates" operate under the party bureaus and coordinate the higher-level propaganda work. For example, in the Hajdu-Bihar District there are seventy leading propagandists ; many of them are university instructors, leading party functionaries, or managers. In the various propaganda courses, this elite guard was in direct contact with about sixty thousand workers and disseminated information about the questions of party policy. ${ }^{21}$ Even more important, the new instructional centers provide theoretical and

nominating committee or by any member of the organization and must win a minimum 51 percent of the votes; see "Report About the Election Meetings of the Party Organizations," Népszabadság, Oct. 24, 1968, p. 3.

19. László Rózsa, "Half-Way," Népszabadság, Dec. 1, 1968, p. 3; for the importance of the party in the economy, see also Népszabadság, May 25, 1969, p. 3.

20. Népszabadság, Feb. 8, 1969, p. 3, and May 17, 1969, p. 5.

21. "Ideological Center in the Counties," Népszabadság, Feb. 2, 1969, p. 6. 
practical help to those high school instructors who teach the questions of Marxism-Leninism in the schools. Centralization of propaganda work is said to have had a beneficial effect upon literary and artistic life as well as upon the mass entertainment programs.

The strengthening of party influence was most significant in the educational institutions. After 1965 the Ministry of Education undertook the gradual introduction of the new subject "The Foundations of Our Ideology" into the high schools. The new course is the principal channel for ideological communication between the younger generation and the party and deals mainly with two areas: Marxism-Leninism and the social, economic, and political organization of the socialist society. Thus the party fights a two-pronged ideological battle -in adult education through party propaganda centers and in the schools through the courses in ideology. The crucially important role of the party is officially emphasized: "The educational system and the schools are in the center of the attention of the party and this will remain so." 22 Although there is considerably more intellectual and literary freedom than before, the heavy influence of Marxism-Leninism is felt everywhere, including the schools and universities and particularly in the field of the social sciences. Thus the more liberal atmosphere of the economic reform is counterbalanced by the ideological controls, which are firmly in the hands of the party.

The MSZMP itself is regarded as the vanguard of the working class, and the importance of the members' dedication to the public interest is officially stressed. However, personal interests frequently take priority. Many party members take advantage of their high managerial posts to acquire private property and other material goods. This practice is widespread enough to have warranted a serious warning by the party, which has declared such behavior by party members to be legal but unethical. ${ }^{23}$

In summary, the central directing role of the MSZMP was not only retained but somewhat strengthened after Czechoslovakia. The internal organization of the party continues to be based on the key principle of democratic centralism, and no intraparty opposition is tolerated.

\section{Government Institutions and Democracy}

Although there was a partial reorganization of government organs in conjunction with the introduction of the NEM (largely in the economic and cooperative sphere), no fundamental change took place within the government machinery.

22. See Eva Katona, journalist, "Ideology, Conviction, School," Társadalmi Szemle, July 1968, pp. 62-63.

23. József Horváth, "Voluntarily Undertaken Obligation," Népszabadság, Mar. 27, 1969, p. 3; see also "Communist Ethics and Political Responsibility," Népssabadság, Apr. 27,1969, p. 3. 
The new system of parliamentary elections, which provides for the election of representatives in individual districts, contributed to a somewhat closer relation between the constituencies and their representatives but did not lead to a substantial broadening of the function of the National Assembly. Although there is more active debate, all important decisions are made by the MSZMP, and it is stressed that the deputies represent not only the electors but also the Patriotic People's Front, the party, and the government. The limited role of the Parliament is obvious in the light of the complete absence of dissent and the fact that the 1969 budget was debated and accepted in only three days. It is also an admitted fact that the members of the legislature, on meeting with their electors, frequently turn to the party leaders present and request them to answer the questions. ${ }^{24}$

According to the steadfast policy of the MSZMP, the party has a leading and controlling role in the operation of government organs. This position of the party organizations was clearly stated after the economic reform and especially after the invasion of Czechoslovakia. As an eminent party secretary expressed it: "In principle, there is no question with regard to the operation of the governmental organs, which are beyond the limit of authority of the party organizations. . . The heads of government organs are obligated to inform the party about professional and political questions."25

Thus the party secretary's regular participation in the management conferences became a routine procedure: "The party organizations represent the main supportive and controlling force in the leadership of the governmental organs." ${ }^{26}$ The expanded role of the party in government is designed to balance anticipated centrifugal tendencies which may set in because of the economic decentralization and the transfer of some decision-making power to the lower level. Nonetheless, further lip service is paid to the idea of democratization: "Our government works toward the development of the democratic institutions in all areas and by all possible means," declared the chairman of the Council of Ministers in the National Assembly. However, this statement was accompanied with the warning that the government feels it necessary to strengthen "citizendiscipline" and to broaden the socialist work competition. ${ }^{27}$

On the positive side the government seems to place more emphasis upon the satisfactory handling of the citizens' affairs, and there appears to be a fresh sincerity in dealing with complaints and suggestions, especially on the local

24. Magyar Nemzet, Dec. 18, 1968, p. 1.

25. Statement by Dr. Gyula Szilágyi, candidate of biology and secretary of the party organization in the Agricultural Research Institute of the Hungarian Academy of Sciences, Népszabadság, Oct. 9, 1968, p. 5. The italics are mine.

26. "Communists in the Administrative Agencies," Népszabadság, Feb. 8, 1969, p. 3, and May 17, 1969, p. 5.

27. Statement of Jenठ Fock, chairman of the Council of Ministers, Magyar Nemzet, Oct. 17, 1968, p. 3. 
level. Humane, speedy, and conscientious administration is stressed as an important ingredient of democratism, and the available evidence indicates an improvement in this area. ${ }^{28}$ Although citizens' complaints and demands do not affect higher policy decisions, they seem to have some effect upon secondary or local matters. The more sensitive response of the local government organs may enable the people to feel that there is increased mutuality in the relationship between them and the administrative agencies, and this slight change can be regarded as a modest broadening of popular influence upon the administrative agencies. ${ }^{29}$

The authority of the county councils became enlarged because of the transfer of some powers from the higher governmental organs : 70 percent of the 1969 budget expenditures will be paid by the councils and only 30 percent by state dotations. The local organs also will have more discretionary power in using their surplus revenues as well as their savings from more economical operations.

The principle of double subordination was terminated in the council administration, and various government decrees promoted the transfer of certain jurisdictions to the lower levels. ${ }^{30}$ However, the decentralization was slowed down because the county councils were reluctant to transfer those jurisdictions to the district, city, and village councils. ${ }^{31}$ To improve the quality of administration, new specialized departments were organized in 1968, but the local councils do not have enough expertise to deal with the new problems, and as a consequence decentralization has proceeded in a somewhat chaotic and inconsistent manner. ${ }^{32}$ This so-called county-centralism shows the internal resistance against the new economic reforms, which some Western analysts anticipated. The party and the government inveigh against these obstacles, declaring that "the slowness of the decentralization, the unjustifiable delays in implementing it, is a violation of the spirit of the reform and prevents the steady development of socialist democracy." ${ }^{33}$ It is suggested that more effort is needed to solve the problems, but it is expected that the local councils will continue to be directed by the central government; the principle of democratic centralism makes it imperative that direction from above will be retained in the entire state apparatus. $^{34}$

28. Népszabadság, Feb. 8, 1969, p. 3 .

29. A basically similar trend in the USSR was analyzed by James $H$. Oliver in "Citizen Demands and the Soviet Political System," American Political Science Review, 63 (1969) : 465-75.

30. Népszabadság, Apr. 1, 1969, p. 5, and also Apr. 23, p. 5.

31. Dr. József Varga, candidate of the Academy of Sciences, "Theoretical Questions of the Development of the Council System," Társadalmi Szemle, May 1969, pp. 3-13.

32. Dr. György Gonda, chairman of the Executive Committee of Vas County Council, "About the Increase of the Councils' Role," Tarsadalmi Szemle, June 1969, pp. 65-68.

33. Eva Terényi, "Jurisdictions and Councils," Népszabadság, Nov. 9, 1968, p. 5.

34. Varga, "Theoretical Questions" (see note 31). 
The judicial policy of the government is based on the principle of socialist legality and strict law enforcement, and the importance of the preventive effect of punishment is stressed. The minister of justice reported a substantial increase in serious violations of criminal law, including "hooliganism." Many of the violators were recidivists, and the corrective measures applied by the courts remained ineffective in many instances. Therefore, the government proposed the imposition of the most severe punishments "in the interest of the socialist society," and in making their decisions, the judges, as defenders of socialist legality, were requested to consider the "true interest of the working people." 35

However, while the government represented a hard line in the enforcement of the legal order, there was some broadening of the judicial power on the lower level. The new Misdemeanor Law, implemented on October 1, 1968, created new committees to deal with such offenses; the members of the committees are elected by the local councils from "social activists"- that is, politically active members of the party and/or the mass organizations. Since the councils themselves are controlled by the party, the new collective courts can hardly be regarded as truly democratic institutions. ${ }^{36}$

To summarize, there was no fundamental reorganization of the government organs after the implementation of the NEM, though there were some changes in the direction of a better administration and more meaningful popular participation in government affairs. Nevertheless, after Czechoslovakia, the party has shown increased caution with respect to government organs and continues to keep them under its control.

\section{The Role of the Mass Organizations}

In conjunction with the implementation of the NEM, there was much talk about the enlarged role of the labor unions in mediating conflicts and defending the rights of the workers. However, since the summer of 1968, the discussion of the position of the unions has somewhat regressed to earlier lines. Increasing stress has been placed on the orthodox view that the unions have a major role in promoting higher production and socialist work-competition as well as in strengthening labor discipline. ${ }^{37}$

35. Statement by Dr. Mihály Korom, minister of justice, Magyar Nemzet, Nov. 17, 1968, p. 3.

36. "Local Courts in the Villages," Népszabadság, Dec. 4, 1968, p. 3. Such "social courts," especially in small communities, are likely to generate much resentment and may be conducive to the creation of new tensions. However, there is no available data at present for an evaluation of the new system. Official statistics show that 37 to 42 percent of the earlier social courts, organized in 1964 at the places of work, exist only nominally, and those that are operative deal with only a few cases per year; see Népszabadság, Apr. 17, 1969, p. 3.

37. Statement by Dr. Sándor Beckl, secretary, on the meeting of the National Council of Labor Unions (SZOT), Népszabadság, Dec. 12, 1968, p. 3. 
Although it is true that the role of the unions is enlarged in some areas, for example in the planning and distribution of premiums, the practice of the new veto right is severely restricted. The local organs may initiate a veto, but they must first discuss it with the higher organ and with the party organization. Furthermore, the veto was used infrequently and only in matters of minor importance; it has been officially acknowledged that at the end of 1968 "there was no satisfactory information available about the practice of the veto."38

Although the threat of the veto is said to be enough to prevent management from making objectionable decisions, the subordinate position of the unions makes possible certain compromises in which the union has to yield, or the veto is not used at all because of pressure by the party or management or both. It is also emphasized that the veto is a means of suppressing resolutions which would be contrary to the nature of the socialist system. This puts the stress on the interest of the national economy as against that of the individual or collective. Thus the labor unions do not play the decisive role as regulators of group conflicts; this function is fulfilled by the party, which has the ultimate power.

Early in 1968 the independent role of the unions was strongly emphasized, but after the invasion of Czechoslovakia the party went on the offensive again, and its primacy in the work of the unions is repeatedly stressed. The unions generally are not in a position to suggest policies different from those of the party or government and, because of the heavy influence of the former, cannot act as independent pressure groups. Nor can the other mass organizations, which are coordinated with the Patriotic People's Front, through which the people are supposed to participate in the political process. The PPF is under the control of the party and accepts its policies without offering substantial criticism. The role of the PPF has been stressed since the Ninth Party Congress, but the renewed emphasis upon the cooperation between the PPF and the mass organizations is not new and cannot be regarded as an aspect of democratization.

It is made abundantly clear that all mass organizations-including the unions-are under the leadership of the party. As a leading authority of the unions expressed it: "In the political preparation of the union work, in the selection of cadres, in the formulation of reports and analysis of situations, the active help and contribution of the party organizations is indispensable."39 Therefore, the MSZMP lays great stress on the active participation of the party and its members in the work of the mass organizations and in solving problems

38. Ibid. The first significant veto was cast in April 1969, in the Athaeneum Printing Office in a disagreement between the local labor union and management. In the report about this case the lack of the application of the veto is criticized; see Népszabadság, June 1,1969 , p. 6.

39. Gábor Somosk8i, secretary of the SZOT, "The Confidence of the Workers," Népszabadság, Jan. 12, 1969, p. 1. 
on the enterprise level; any weakness of the party organizations in these areas is severely criticized by the higher organs.

\section{Group Conflicts}

The economic reform had a substantial influence upon various group interests by intensifying competition among them. This is observable on the horizontal level (between occupational interests) and on the vertical level (between individual, collective, and social interests). Another category is functional-“consumer-interest," "producer-interest," and the like. There are also some conflicts observable within each group. ${ }^{40}$ According to the official position, such conflicts are not fundamental because group interests must be in harmony in a socialist system. Thus individual interest is served by more productive work and ensuing higher material rewards; collective interest is best promoted by the higher profitability of the enterprise; and the social interest demands an increase in gross national product. ${ }^{\mathbf{1 1}}$

However, decentralization in planning and the broadened autonomy of the local governments and enterprises have intensified group conflicts by creating competitive situations in a more profit-oriented economy. The lack of "social consciousness" in the society contributes to the sharpening of group conflicts; the behavior of the workers and peasants is still quite frequently individualistic and gives preference to individual rather than social interests. The chairman of the Council of Ministers stated that there is no national unity in Hungarian society because many people give priority to their own interests at the expense of the community-adding that repressive measures would be taken against those who cause harm to the socialist interest. ${ }^{42}$ It is obvious, then, that the philosophy of communism has not impregnated Hungarian society deeply enough, with the consequence that "antisocial" attitudes gain expression through the channels of group conflicts and play the role of cause and effect at the same time-that is, individualistic behavior contributes to group conflicts, and is also reinforced by them.

Within the framework of this broader conflict one of the most serious cleavages is that between the industrial and agricultural workers. The Hungarian peasantry, like their counterparts in the rest of the East European bloc, bore the heavy burdens of industrialization, and their economic status has been far inferior to that of the working class. However, the government has recently turned its attention to this hitherto neglected class and begun to take serious steps to improve the economic and cultural standards of the peasants. Im-

40. Nyers, "The Impact of the Economic Reform," pp. 7-21.

41. Kállai, "Economic Reform," p. 11.

42. Népszabadság, Jan. 3, 1969, p. 3. 
plementing the resolutions of the Ninth Congress of the MSZMP, the government introduced incentives into the price system and raised the wholesale prices of agricultural goods by 17 percent, extended the pension and social insurance coverage of the agricultural population, introduced new measures in the dotation of the underprivileged cooperatives, and generally attempted to narrow the gap between the industrial workers and the peasantry. The policy resulted in a substantial improvement in some segments of the agricultural population, ${ }^{43}$ which, in turn, caused resentment in the industrial workers, who have frequently felt that they are the stepchildren of the system because persons in management, the party, and the government bureaucracy, and now many peasants are in a much more favorable situation. Nevertheless, the party and the government defend the policy as being sound and stress the belowstandard status of some segments of the agricultural population.44

The intensified group conflict in a society which has now become somewhat more pluralistic is especially observable in the area of wage and premium distribution. Two main categories of friction can be identified: friction between managers and workers, and between the workers themselves. In this officially classless society serious opposition has developed against the differentiated wage system and the disproportions in premium distribution. To cushion the seething resentment against the premium distribution system, some enterprises have paid bonuses in secret. ${ }^{45}$ Nevertheless, the facts became known and created turbulent disagreements leading to criticism that some workers were paid excessive premiums while the rest received only token amounts. To correct the problem the party recommended that secrecy be done away with and the higher premiums reduced, but it also took a strong position against egalitarian tendencies.

The workers resent the higher income of the managerial class even more strongly than they resent the higher premiums paid to their fellow workers. The hostile attitude toward management is so widespread that it cannot be denied and is even the subject of some humorous stories in the party press. In some cases the workers' resentment of higher premiums may be simply a rationalization for hostilities that have much deeper and more complex roots. ${ }^{46}$ The often vehement rejection of the "privileged" position of managers is

43. Wages for the skilled workers in cooperatives are frequently much higher than in industry, resulting in a reverse-flow of labor from the industrial to the agricultural sector of the economy, Népszabadság, Jan. 31, 1969, p. 3.

44. For a detailed analysis of the question see Dr. Sándor Zsarnoczai, university docent, "Peasant Incomes and Living Standards," Társadalmi Szemle, June 1969, pp. 12-27.

45. See "Working Days in the May 1st Clothing Factory," Népszabadság, Oct. 30, 1968 , p. 6. p. 6.

46. "Conflicts, Misunderstandings and Embarrassments," Népszabadság, Dec. 11, 1968, 
frequently justified by a certain "vulgar Marxism," according to which "the profit is produced by the workers and the director has a high salary anyway; thus his higher premiums are not justified."

Hostile attitudes toward white collar workers are also observable and find expression in exaggerated notions about their income and salary. The party tries to correct such views by stressing the contributions of the managers to the increase in output and thus to higher profitability and better premiums. Therefore, it is argued, the egalitarian views of many workers are fundamentally wrong and must be either corrected or suppressed because premium distribution based on merit is in the best interest of the entire socialist society. ${ }^{48}$ However, the workers' demand for more equality is so widespread and their dislike of the merit system so strong that the National Council of Labor Unions felt it necessary to declare that in political propaganda work there must be more stress on the proper understanding of socialist equality and suggested that more effort be made to combat and overcome the widespread practice of egalitarianism.

Individual self-interest, envy, and strong group interests are the powerful motives for the workers' behavior. Obviously, individual, group, and social interests are frequently on a collision course, and the party often stresses that the integration of competitive interests is a continuing task which must be carried out under the direction of the party. ${ }^{49}$ The heightening of group conflicts has provided opportunities for the pursuit of egotistic tendencies. The party and government have reacted with renewed warnings about the dangers of "selfishness and materialism caused by those who completely disregard the interests of socialism," suggesting, in effect, that the success of the economic reforms depend on the attitude of the workers. Nonetheless, it is officially recognized that such things cannot be changed overnight: "We have to accept the fact that there are and there will be in the foreseeable future, many people who in the period of the building of socialism, are exclusively concerned now and evermore with their own interests."

A lack of dedication and apathy toward work and professions is a characteristic phenomenon in Hungary as well as in the entire East European bloc. This is obvious to the Western observer and has been recognized by leading intellectuals and politicians in the Soviet bloc. ${ }^{51}$ The party tries to combat this

47. See Népszabadság, Mar. 25, 1969, p. 5. For a reference to popular views, according to which the differentiated premium-distribution system contributes to social conflicts and creates contradictions in the society, see "Problems of the Economic Reform," lecture by József Bálint, head of the Department of the Economic Policy of the Central Committee, on the Political Academy of the MSZMP, Népszabadság, May 23, 1969, pp. 4-5.

48. Népszabadság, Mar. 25, 1969, p. 5.

49. Népszabadság, Feb. 6, 1969, p. 5.

50. Statement by Jenö Fock, Népszabadság, Jan. 3, 1969, p. 3.

51. With reference to Czechoslovakia, see "A 'Common Cause': The 2000 Words," 
phenomenon but with less than satisfactory results. Neglect, laziness, low productivity, and irresponsibility are frequent subjects for serious speeches and articles and are bitterly satirized in the humor magazines.

Finally, another aspect of the growing group conflicts has to be mentioned -the deplorable treatment of the workers by management. In Budapest alone there were hundreds of cases in a single year in which workers left their enterprises because of inhuman and contemptuous treatment by the management, which exhibited lack of concern for their problems. Management in these cases was primarily interested in profit-making and efficient operations. Since the workers received only a small bonus from higher profits, their disillusionment is not surprising. Furthermore, in spite of the continued talk about democratization on the enterprise level, persons who criticized the management frequently experienced open or subtle reprisals-another factor that depressed the already low morale of the workers. ${ }^{52}$

In conclusion, it is apparent that the NEM is conducive to the sharpening of group conflicts. This trend is acknowledged by the party but is somewhat played down. The theoretical journal of the party emphasized that the decisions of the Ninth Congress contributed to the "growth of the particular interests" and raised the question of the proper method of conflict resolution. However, no satisfactory solution has been suggested so far, other than a renewed stress on the party's role and vague proposals for some representation of the various interests in the state organs. The question is of major importance, and calls for serious scientific inquiry; however, Hungarian sociology, plagued by political dissent concerning its nature and function in a socialist society, has failed to contribute to a better understanding of the problem. ${ }^{\text {B3 }}$

\section{Summary and Conclusions}

In conjunction with the implementation of the NEM, the MSZMP and the government stressed the importance of democratization for the success of the new economic policy. The general atmosphere during the spring of 1968 was conducive to more significant political changes: the party was on the defensive and was trying to fend off subtle pressures to contract its power and to keep the explosive Czechoslovakian issue from the forefront of public interest. However, as the Czechoslovakian reform movement unfolded, the Hungarian Communist Party became increasingly articulate in defending its concept of democracy. After the Soviet intervention the MSZMP moved

Problems of Communism, November-December 1968, pp. 12-13; with reference to Hungary, see Charles Derecskei, "To the Tick of a Different Clock," Atlantic Monthly, February 1969, pp. 74-83.

52. Népszabadság, Mar. 19, 1969, p. 3.

53. See Dr. Laszló Molnár, professor of sociology at the Political Academy, "Thoughts About the Social Functions of Sociology," Társadalmi Szemle, December 1968, pp. 87-91. 
determinedly toward the offensive and reasserted the Leninist definition of democracy-the dictatorship of the proletariat. Thus the concept of democracy remained orthodox. Even if there had been some expectation prior to the invasion of Czechoslovakia that a more truly democratic system would develop, these hopes quickly faded afterward and general cautiousness set in. Concessions toward a genuine participation in the political process are token, and they aim merely at better mass support of the official policy. This is not a new phenomenon in the people's democracies, but the Hungarian party and government seem to have a more sincere interest in it than before.

At the same time that the economy was being decentralized, the party's role in the management of enterprises and government organs became somewhat enlarged. Democratic centralism remained the leading principle of "intraparty democracy," and although there was more independent decision-making by the members on the 1968 party elections, the controlling position of the higher organs over the lower ones was maintained.

The MSZMP also retained its control over the mass organizations, and it now fights a two-pronged propaganda battle through the newly created instructional centers and the ideological courses in the school system. Thus the leading role of the party is unchallenged, and it has been unequivocally declared that "the party has no intention of abdicating its power monopoly." abundantly clear that the NEM did not precipitate major changes in the party, and that after the invasion of Czechoslovakia neither was intraparty opposition tolerated nor was there a genuine move toward a more democratic party organization.

In the government organs the controlling position of the party became strengthened after the implementation of the NEM. This new role assures the central direction of the party, parallel with the structural decentralization in government and the economy, and acts as a counterweight against centrifugal forces in a more pluralistic society. In order to secure leadership a firmer citizen discipline is required, and to cushion discontent a partly sincere approach was made toward a more humane administration. But no important changes took place in the representative institutions-that is, no real debate takes place in the Assembly and no opposition is tolerated.

Within the local councils, decentralization of budget and other authorities resulted in a more autonomous administration, and thus decision-making is now somewhat closer to the grass-roots level. However, a newly emerged "microcentralism" hinders the transfer of power to the lower organs. The judicial authorities are struggling with the growing crime rate and "hooliganism," and are applying harsh repressive measures, which can hardly be regarded as a trend toward genuine democratization.

54. Statement by Béla Biszku, Társadalmi Szemle, January 1969, pp. 5-6. 
Although the unions have an enlarged role, they continue to operate under party control. The veto right could be a substantial enlargement of the union's power, but it has scarcely been used. Since the summer of 1968 , the discussion of the function of the unions has somewhat regressed to earlier views with strong emphasis on the importance of the discipline and morale of the workers. In addition, all mass organizations continue to be under the leadership of the party.

The enlarged autonomy of the enterprises, the new incentive system, and the prevailing "individualistic" attitudes have intensified group conflicts in the more profit-oriented economy. Serious tension is observable between the agricultural and industrial workers as a result of recent efforts by the government to improve conditions in the countryside. However, the gravest conflicts arose because of the differentiated wage and premium system. Individual, group, and social interests are frequently on a collision course, but the government stresses the importance of the "socialist conscience" and the primacy of public good.

The large-scale discontent with the premium distribution system must be regarded primarily as a protest against the income differences between the various strata of society. But underneath the economic dissatisfaction there may be other even more significant reasons for this situation. Undoubtedly opposition against the higher incomes of the managerial class can be freely expressed, but the fundamentals of socialism cannot be questioned. It is likely, therefore, that in many instances criticism of the premium distribution and animosity against the managers on that basis is actually a displaced hostility against the entire political system. Thus in some respects the group conflicts may be regarded as a manifestation of latent political opposition.

The broadening of the conflicts between different groups is evidence of a more pluralistic society. However, at present the conflicts are limited, and pluralism is subdued by the regulatory agencies-the party and government. If present trends continue, short of fundamental changes in the political institutions, it is not likely that the group conflicts will lead to a truly pluralistic and thus more democratic society, and that the current-often serious-tremors can be brought to equilibrium by perceptive and cautious policies.

In the aftermath of Czechoslovakia the government and the party applied the brakes to political reforms. While the general direction of policy remains the same and centers on a genuine effort to create a healthier economy, more prudence is being used in achieving this goal and preventing the erosion of firm controls in the hands of central authorities. If there was any doubt about what sort of democracy was supposed to accompany the reform, such uncertainties are now carefully avoided: the orthodox concepts of socialist democracy have been firmly restated.

In accordance with the foregoing analysis, no meaningful institutional 
reforms can be expected in the foreseeable future. However, an opposite view has been expressed by Dr. Michael Gamarnikow, who recently suggested that in the East European countries, despite the events of 1968, organized opposition may emerge and "the advocacy of basic policy alternatives will become a normal and accepted pattern of political behavior in a pluralistic socialist system." ${ }^{55}$. With respect to Hungary, his opinion is based on the contention that a transfer of power from the party to the state is in process, together with a genuine broadening of the role of the representative institutions, and furthermore that the trade unions may become true agents of special interest groups and that the influx of technocrats in leading posts will erode the power monopoly of the party.

This author questions the validity of these observations. The evidence in the present study does not substantiate Dr. Gamarnikow's views about the emergence of a pluralistic political system because of economic exigencies. There is ample proof that the party is not transferring its power to the state and that it continues to dominate mass organizations, including trade unions. Group conflicts, although significantly intensified under the economic reforms, are controlled by the party, and the primacy of public interest is firmly established.

The New Economic Mechanism is retained as the basic policy of the government and has resulted in certain improvements. The general atmosphere in Hungary in 1969-70 has been somewhat more liberal, but basic political changes have not taken place. The party and government strictly follow the foreign policy of the Soviet Union, as is demonstrated by the endorsement of the "Brezhnev doctrine." The Hungarians are conducting a cautious, middleof-the-road domestic policy that maneuvers carefully between the too bold reforms of the Dubček era and the current Czechoslovakian reaction. The present collective leadership is considered politically mediocre and will not take risks to experiment with meaningful change in the status quo. It is likely that contrary to Gamarnikow's views the present trend will continue, because the ruling elite, given the choice between a more efficient economy and the preservation of power, will undoubtedly opt for the latter. However, the party and government can be expected to be further concerned with greater mass participation in the political process and with a more humane administration. This is regarded as essential for the success of economic reforms and the taming of public discontent. The limits of change are those of stability and survival of the socialist system as interpreted by the ruling elite.

55. Michael Gamarnikow, "Political Patterns and Economic Reforms," Problems of Communism, March-April 1969, pp. 11-23. 